\title{
In vitro evaluation of Saanen buck semen frozen in different extenders supplemented with various antioxidants"
}

\author{
Recai KULAKSIZ ${ }^{1}$, Ali DAŞKIN ${ }^{1}$ \\ ${ }^{1}$ Department of Reproduction and Artificial Insemination, Faculty of Veterinary Medicine, University of Ankara, 06110, Ankara, \\ Turkey.
}

\begin{abstract}
Summary: The aim of this present study was to investigate the effects of extenders containing different antioxidants upon the principle sperm characteristics of Saanen buck semen following freezing. In this study, four bucks were used. Semen was collected twice a week by an artificial vagina during the breeding season to obtain ten ejaculates per animal. The samples were then extended in three extenders (tris, T-, skimmed milk, M- and laiciphos 488, L- based) without (as controls) or with the two antioxidants (5 mM cysteine, $\mathrm{C}$ and $1000 \mu \mathrm{g} / \mathrm{ml}$ hyaluronic acid, H). By this way, nine experimental groups were assigned, as follows: T-C, T-H, T-O (control); M-C, M-H, M-O (control); L-C, L-H, L-O (control). For the T extender groups, the rates of motility and viability were significantly $(\mathrm{p}<0.01)$ higher for the T-C extender as compared to those of the T-H and T-O. However, there was no such difference ( $>0.05$ ) among the extenders based on the rates of abnormal spermatozoa, abnormal acrosome and hypoosmotic swelling (HOS) test. For the M groups, the motility was significantly $(\mathrm{p}<0.01)$ higher for the M-C and M-O extenders as compared to that of the M$\mathrm{H}$. However, there was no such difference $(\mathrm{p}>0.05)$ among the extenders based on the rates of viability, abnormal spermatozoa, abnormal acrosome and HOS test. For the L groups, the rates of motility and viability were significantly $(\mathrm{p}<0.01)$ higher for the L-C extender as compared to that of the L-H but not that of the L-O. Additionally, there was no such difference ( $>>0.05)$ among the extenders mentioned above based on the rates of abnormal spermatozoa, abnormal acrosome and HOS test. As a result, the present in vitro findings of semen quality parameters studied suggest that; i) both skimmed milk and laiciphos extenders were more favourable than tris, and that ii) the cysteine, as an antioxidant, provided a superior protection than the hyaluronic acid did.
\end{abstract}

Key words: Antioxidants, in vitro evaluation, Saanen buck, semen extension, semen freezing

\section{Farklı antioksidanlar eklenmiş sulandırıcılarla dondurulmuş Saanen tekesi spermasının in vitro değerlendirilmesi}

Özet: Sunulan çalışmada, Saanen teke spermasının farklı antioksidanlar içeren sulandırıcılarla dondurulmasının başlıca spermatolojik özellikler üzerine etkileri araştırıldı. Araştırmada, dört adet teke kullanıldı. Her bir tekeden aşım mevsiminde suni vajen yardımıyla haftada iki kez toplam on ejekulat alındı. Split-sperma örnekleri, üç farklı sulandırıcı (tris, T-, yağsız süt tozu, Y- ve laiciphos 488, L) ve iki farklı antioksidan (5 mM sistein, S ve $1000 \mu \mathrm{g} / \mathrm{ml}$ hyaluronik asit, H) kullanılarak, antioksidan kullanılmadan (kontrol grupları) sulandırıldı. Böylece, örnekler toplam dokuz ayrı çalışma grubuna ayrıldı: T-S, T-H, T-K (kontrol); Y-S, Y-H, YK; L-S, L-H, L-K. T sulandırıcı grupları için, T-S grubundaki motilite ve canlılık oranları, T-H ve T-K gruplarındaki oranlardan istatistiksel olarak daha yüksek $(\mathrm{p}<0.01)$ olmasına karşın, anılan gruplar arasında anormal spermatozoa, anormal akrozom ve HOS testi oranları yönlerinden önemli bir fark belirlenmedi $(\mathrm{p}>0.05)$. Y grupları için, Y-S ve Y-K sulandırıcı gruplarındaki motilite oranları, Y-H grubundaki orandan daha yüksek $(\mathrm{p}<0.01)$ olmasına karşın, gruplar arasında canlılık, anormal spermatozoa, anormal akrozom ve HOS testi oranları yönlerinden önemli bir fark belirlenmedi ( $>0.05)$. L grupları için, L-S grubundaki motilite ve canlılık oranlar1, L-H grubundaki oranlardan daha yüksek $(\mathrm{p}<0.01)$ iken, L-K grubundaki değerlerden ise önemli bir farklılık belirlenmedi $(p>0.05)$. Ayrıca, anılan gruplar arasında anormal spermatozoa, anormal akrozom ve HOS testi oranları yönünden önemli bir fark belirlenmedi ( $p>0.05)$. Sonuç olarak, sunulan çalışmada elde edilen in vitro sperma kalitesi bulgularına göre; i) yağsız süt tozu ve laiciphos sulandırıcısının tris sulandırıcından daha üstün olduğu, ayrıca ii) sisteinin bir antioksidan olarak hyaluronik asitten daha iyi koruma sağladığı kanısına varıldı.

Anahtar sözcükler: Antioksidanlar, in vitro değerlendirme, Saanen tekesi, spermanın dondurulması, spermanın sulandırılması.

\section{Introduction}

In Turkey, the existing population of goats is over 6.5 million. Anatolian black goats are seen as a widespread breed across the country but are low-yielders.
Since the native breeds are mostly poor producers, attempts to improve the production parameters are needed. To this aim, it is well-known that, a Saanen goat breeding programme was initiated under the conditions

\footnotetext{
${ }^{*}$ This study is a part of $\mathrm{PhD}$ thesis (in Turkish) of the first author.
} 
of Çukurova region in 1973. Hence, the goats of Saanen was the breed of choice (as also adopted herein) because of their high milk yield and fecundity (14).

In semen processing, the extender is a key factor for the sperm cells. Tris- egg yolk- glucose and skimmed milk are the most commonly used extenders for cryopreserving the goat semen. In the literature, both extenders mentioned above have been shown to provide adequate post-thaw sperm parameters in domestic species (21).

A limiting factor in semen preservation is the exposure of sperm to the light during manipulations before the storage, leading to the formation of reactive oxygen species (ROS), which reduce motility and genomic integrity of sperm cells. It is well-known that the functional sperm parameters potentially affected by the ROS, including hydrogen peroxide $\left(\mathrm{H}_{2} \mathrm{O}_{2}\right)$, superoxide anion $\left(\mathrm{O}_{2}^{-}\right)$and/or hydroxyl radical $\left(\mathrm{OH}^{-}\right)$. These substances are very strong oxidants and are physiologically produced within the living cells during the respiration (1). This problem can be overcomed by the addition of antioxidants into the preservation medium (extender). The antioxidant molecules could reduce the impact of oxidative stress and, thus, improve the semen quality after thawing. The antioxidant treatments should not lead to the complete ROS elimination, since the oxidative mechanisms play a crucial role during the physiological control of mammalian sperm functions $(2$, 10, 17).

Mammalian cells can only utilize thiol compounds such as cysteine and glutathione (GSH). These compounds are able to penetrate the cell membrane easily, through enhancing the intracellular GSH biosynthesis both in vitro and in vivo, as well as protecting the membrane lipids and proteins by direct radical-scavenging properties (18). Cysteine has also been shown to prevent the losses in the motility of frozen-thawed ram (26) and goat semen (6).

Recently, several reports suggested that glycosaminoglycans (GAGs) possess antioxidant properties. Hyaluronic acid was shown to inhibit lipid peroxidation by chelating the transitional metal ions, such as $\mathrm{Cu}^{2+}$ or $\mathrm{Fe}^{2+}(5)$.

Therefore, the aim of the present study was to evaluate the post-thaw quality of buck semen extended with different diluents containing various antioxidants.

\section{Material and Method}

Animals and semen collection: Four healthy, sexually mature bucks of Saanen breed were used in this study. The animals were housed at the Research and Practise Farm (Faculty of Agriculture, Ankara University, Ankara, Turkey) under uniform feeding, housing and light conditions. The routine feeding programme of the farm was also applied for the experimental animals. The animals had a free access to dry grass-hay and drinking water and they were also fed with some concentrates including minerals. The ejaculates (10 samples per buck) were collected twice a week by an artificial vagina during the breeding season (between late October to early November). The semen samples were collected and immediately immersed into a water bath at $30^{\circ} \mathrm{C}$ until the assessment of sperm parameters in the laboratory within approximately $20 \mathrm{~min}$.

Extenders and antioxidants: In the present experiment, three semen extenders (tris, skimmed milk and laiciphos 488- based) and two antioxidants (5 $\mathrm{mM}$ cysteine and $1000 \mu \mathrm{g} / \mathrm{ml}$ hyaluronic acid) were tested. The contents of tris- (Extender T), skimmed milk- (Extender $\mathrm{M}$ ) and laiciphos-based extenders (Extender L) without (Extenders $\mathrm{T}-\mathrm{O}, \mathrm{M}-\mathrm{O}$ and L-O) or with cysteine (Extender T-C, M$\mathrm{C}$ and L-C) and hyaluronic acid (Extenders T-H, M-H and $\mathrm{L}-\mathrm{H}$ ) are given in Table 1. For freezing, all the extenders (to be T, M and L) were supplemented with $10 \%$ egg yolk and 5\% glycerol. Eventually, nine experimental groups were assigned, as follows: T-C, TH, T-O (control); M-C, M-H, M-O; L-C, L-H, L-O. The $\mathrm{pH}$ of extenders was equally adjusted to 7.0.

Table 1. Extender compositions ${ }^{*}$ Tablo 1. Sulandırıcı içerikleri

\begin{tabular}{lcccc}
\hline Contents & Unit & T-O & T-C & T-H \\
\hline Tris base & $\mathrm{mM}$ & 375 & 375 & 375 \\
Citric acid & $\mathrm{mM}$ & 125 & 125 & 125 \\
Glucose & $\mathrm{mM}$ & 41 & 41 & 41 \\
Cysteine & $\mathrm{mM}$ & - & 5 & - \\
Hyaluronic acid & $\mu \mathrm{g} / \mathrm{ml}$ & - & - & 1000 \\
& & & & \\
& & $\mathrm{M}-\mathrm{O}$ & $\mathrm{M}-\mathrm{C}$ & $\mathrm{M}-\mathrm{H}$ \\
\hline Skimmed milk & $\mathrm{g} / \mathrm{l}$ & 100 & 100 & 100 \\
Glucose & $\mathrm{g} / \mathrm{l}$ & 9 & 9 & 9 \\
Cysteine & $\mathrm{mM}$ & - & 5 & - \\
Hyaluronic acid & $\mu \mathrm{g} / \mathrm{ml}$ & - & - & 1000 \\
& & & & \\
& & $\mathrm{~L}-\mathrm{O}$ & $\mathrm{L}-\mathrm{C}$ & $\mathrm{L}-\mathrm{H}$ \\
\hline Laiciphos 488 & $\mathrm{g} / \mathrm{l}$ & 100 & 100 & 100 \\
Cysteine & $\mathrm{mM}$ & - & 5 & - \\
Hyaluronic acid & $\mu \mathrm{g} / \mathrm{ml}$ & - & - & 1000 \\
\hline
\end{tabular}

* All the extenders contained $50 \mathrm{mg}$ streptomycin and 50,000 UI penicillin, $100 \mathrm{ml}$ egg yolk and $50 \mathrm{ml}$ glycerol per litre (1000 ml).

Semen extending, freezing and thawing: The volume of ejaculates was measured in a conical tube graded with $0.1 \mathrm{ml}$ increments. The sperm concentration was determined by using a haemocytometer. The sperm motility was estimated under the phase contrast microscope (100 x magnification). Only the ejaculates having; i) a volume of one to two $\mathrm{ml}$, ii) progressive 
motility higher than $70 \%$, and iii) spermatozoa concentration higher than $2.5 \times 10^{9}$ sperm $/ \mathrm{ml}$ were pooled. This was mainly to quarentee equal contribution of each male to the pool, avoiding the individual differences.

Following estimation of spermatological characteristics of the ejaculates of individual bucks, each of the pooled samples were divided into nine equal aliquots and diluted (at a concentration of $800 \times 10^{6} \mathrm{sperm} / \mathrm{ml}$ ) in the extenders stated above. Diluted samples were packaged in $0.25 \mathrm{ml}$ French straws, sealed with polyvinyl alcohol powder and equilibrated at $4^{\circ} \mathrm{C}$ for $2 \mathrm{~h}$. After equilibration, the straws were frozen liquid nitrogen vapour for $15 \mathrm{~min}$ and were plunged into the liquid nitrogen. After a month of storage, frozen straws were thawed in a water bath individually at $37^{\circ} \mathrm{C}$ for $30 \mathrm{sec}$ for immediate evaluation.

Semen evaluation: Progressive sperm motility was assessed subjectively under a phase-contrast microscope (100 x magnification) equipped with a heated stage adjusted to $37^{\circ} \mathrm{C}$. Motility estimations of each sample were performed from three different microscope fields by the same person throughout the study. The mean of the three estimations was considered as the final motility score.

To evaluate the live/dead spermatozoa (viability) rate, eosin-nigrosin staining was used, according to the method described by Evans and Maxwell (9). The smears were prepared routinely by mixing one drop of semen sample with two drops of the stain on a warm slide and immediately spreading the stain with one edge of a second slide. The viability was assessed by counting 200 spermatozoa under a phase-contrast microscope (400 x magnification). Stained sperm cells were regarded as dead.

For the sperm morphology assessment, at least two drops of semen were added to Eppendorf tubes, containing $0.5 \mathrm{ml}$ Hancock's solution (23). One drop of this mixture was placed on a microscope slide and then covered with a cover slip. The percentages of abnormal sperm (detached heads, acrosomal aberrations, abnormal mid-pieces and tail defects) were recorded by counting a total of 200 spermatozoa under the phase contrast microscope (magnification x 1000; oil immersion).

The hypo-osmotic swelling (HOS) test was used to evaluate the functional integrity of the sperm membrane, based on the curled and swollen tails. This was performed by incubating $30 \mu \mathrm{l}$ of semen with $300 \mu \mathrm{l}$ of $100 \mathrm{mOsm} / \mathrm{kg}$ hypo-osmotic solution at $37^{\circ} \mathrm{C}$ for $60 \mathrm{~min}$. Following the incubation, $0.2 \mathrm{ml}$ of the mixture was spread with a cover slip on warm slide. A total of 200 spermatozoa was counted (magnification $x$ 400) under a phase-contrast microscope. Spermatozoa with swollen or coiled tails were recorded (22).
Statistictical analyses: The study was repeated 10 times and the results expressed as the mean \pm S.E.M. Means were analyzed by Analysis of Variance (ANOVA), followed by the Duncan test to determine significant differences between the 9 experimental groups and control groups- with additives or no additive after the freezing-thawing process for sperm characteristics using the SPSS/PC version 12.0 software (SPSS, Chicago) (7).

\section{Results}

The average volume of the ejaculates was $1.22 \pm$ $0.23 \mathrm{ml}$, while their average spermatozoa concentration was $3.62 \pm 0.41 \times 10^{9} / \mathrm{ml}$. The ejaculates contained 77.0 $\pm 4.83 \%$ motile and $89.10 \pm 2.93 \%$ viable spermatozoa along with $93.0 \pm 0.88 \%$ intact acrosome (data not shown).

For the T extender groups, the rates of motility and viability $(24.5 \pm 2.29 \%$ and $46.65 \pm 3.51 \%$, respectively) were significantly $(\mathrm{p}<0.01)$ higher for the T-C extender as compared to those of the T-H $(17.0 \pm 1.10 \%$ and 33.18 $\pm 2.06 \%$, respectively) and T-O $(19.5 \pm 1.16 \%$ and 35.02 $\pm 2.56 \%$, respectively). However, there was no such difference $(p>0.05)$ among the extenders based on the rates of abnormal spermatozoa, abnormal acrosome and HOS test (for T-C: $65.75 \pm 2.12 \%, 44.59 \pm 1.44 \%$ and $29.47 \pm 3.09 \%$, for $\mathrm{T}-\mathrm{H}: 68.39 \pm 2.81 \%, 48.79 \pm 2.19 \%$ and $24.73 \pm 3.36 \%$, and for T-O: $69.34 \pm 2.07 \%, 47.04 \pm$ $1.62 \%$ and $26.03 \pm 2.80 \%$, respectively) (Table 2 ).

For the $\mathrm{M}$ groups, the motility was significantly $(\mathrm{p}<0.01)$ higher for the M-C and M-O extenders $(44.0 \pm$ $1.44 \%$ and $39.5 \pm 3.11 \%$, respectively) as compared to that of the M-H $(30.5 \pm 1.57 \%)$. However, there was no such difference $(\mathrm{p}>0.05)$ among the extenders based on the rates of viability, abnormal spermatozoa, abnormal acrosome and HOS test (for M-C: $52.81 \pm 2.65 \%, 52.81$ $\pm 2.55 \%, 35.95 \pm 2.1 \%$ and $43.44 \pm 3.69 \%$, for $\mathrm{M}-\mathrm{H}$ : $42.13 \pm 1.54 \%, 53.67 \pm 1.92 \%, 38.32 \pm 2.32 \%$ and 41.22 $\pm 3.55 \%$, and for M-O: $47.85 \pm 3.80 \%, 59.14 \pm 2.20 \%$, $40.42 \pm 2.50 \%$ and $46.33 \pm 4.22 \%$, respectively) (Table 3 ).

For the $\mathrm{L}$ groups, the rates of motility and viability $(42.0 \pm 2.49 \%$ and $46.67 \pm 1.77 \%$, respectively) were significantly $(\mathrm{p}<0.01)$ higher for the L-C extender as compared to that of the L-H $(32.0 \pm 1.33 \%$ and $39.59 \pm$ $1.09 \%$, respectively), but not that of the L-O (37.5 \pm $1.86 \%$ and $42.50 \pm 1.56 \%$, respectively). Additionally, there was no such difference $(p>0.05)$ among the extenders based on the rates of abnormal spermatozoa, abnormal acrosome and HOS test (for L-C: $54.78 \pm$ $2.23 \%, 36.31 \pm 1.96 \%$ and $42.75 \pm 2.95 \%$, for $\mathrm{L}-\mathrm{H}$ : $52.44 \pm 2.49 \%, 36.38 \pm 2.39 \%$ and $41.42 \pm 3.20 \%$, and for L-O: $56.34 \pm 2.24 \%, 40.01 \pm 2.73 \%$ and $45.25 \pm$ $2.59 \%$, respectively) (Table 4 ). 
Table 2. Post-thaw spermatologicial characteristics of buck semen frozen in tris extender containing different antioxidants $(\mathrm{n}=10)$ Tablo 2. Farklı antioksidanlar içeren tris sulandırıcısıyla dondurulmuş teke spermasında çözdürme sonrası spermatolojik özellikler $(\mathrm{n}=10)$

\begin{tabular}{lccccc}
\hline Groups & $\begin{array}{c}\text { Motility } \\
(\%)\end{array}$ & $\begin{array}{c}\text { Viability } \\
(\%)\end{array}$ & $\begin{array}{c}\text { Total abnormality } \\
(\%)\end{array}$ & $\begin{array}{c}\text { Acrosomal abnormality } \\
(\%)\end{array}$ & $\begin{array}{c}\text { Host } \\
(\%)\end{array}$ \\
\hline T-O & $19.5 \pm 1.16^{\mathrm{b}}$ & $35.02 \pm 2.56^{\mathrm{b}}$ & $69.34 \pm 2.07^{\mathrm{a}}$ & $47.04 \pm 1.62^{\mathrm{a}}$ & $26.03 \pm 2.80^{\mathrm{a}}$ \\
T-C & $24.5 \pm 2.29^{\mathrm{a}}$ & $46.65 \pm 3.51^{\mathrm{a}}$ & $65.75 \pm 2.12^{\mathrm{a}}$ & $44.59 \pm 1.44^{\mathrm{a}}$ & $29.47 \pm 3.09^{\mathrm{a}}$ \\
T-H & $17.0 \pm 1.10^{\mathrm{b}}$ & $33.18 \pm 2.06^{\mathrm{b}}$ & $68.39 \pm 2.81^{\mathrm{a}}$ & $48.79 \pm 2.19^{\mathrm{a}}$ & $24.73 \pm 3.36^{\mathrm{a}}$ \\
\hline
\end{tabular}

"(a,b): Different superscripts within the same column differ significantly $(\mathrm{p}<0.01)$ ".

T-O: Tris without antioxidant, T-C: Tris with $5 \mathrm{mM}$ cysteine, T-H: Tris with $1000 \mu \mathrm{g} / \mathrm{ml}$ hyaluronic acid

Table 3. Post-thaw spermatologicial characteristics of buck semen frozen in skimmed milk powder extender containing different antioxidants $(\mathrm{n}=10)$

Tablo 3. Farklı antioksidanlar içeren yağsız süt tozu sulandırıcısıyla dondurulmuş teke spermasında çözdürme sonrası spermatolojik özellikler $(\mathrm{n}=10)$

\begin{tabular}{lccccc}
\hline Groups & $\begin{array}{c}\text { Motility } \\
(\%)\end{array}$ & $\begin{array}{c}\text { Viability } \\
(\%)\end{array}$ & $\begin{array}{c}\text { Total abnormality } \\
(\%)\end{array}$ & $\begin{array}{c}\text { Acrosomal abnormality } \\
(\%)\end{array}$ & $\begin{array}{c}\text { Host } \\
(\%)\end{array}$ \\
\hline M-O & $39.5 \pm 3.11^{\mathrm{a}}$ & $47.85 \pm 3.80^{\mathrm{a}}$ & $59.14 \pm 2.20^{\mathrm{a}}$ & $40.42 \pm 2.50^{\mathrm{a}}$ & $46.33 \pm 4.22^{\mathrm{a}}$ \\
M-C & $44.0 \pm 1.44^{\mathrm{a}}$ & $52.81 \pm 2.65^{\mathrm{a}}$ & $52.81 \pm 2.55^{\mathrm{a}}$ & $35.95 \pm 2.13^{\mathrm{a}}$ & $43.44 \pm 3.69^{\mathrm{a}}$ \\
M-H & $30.5 \pm 1.57^{\mathrm{b}}$ & $42.13 \pm 1.54^{\mathrm{a}}$ & $53.67 \pm 1.92^{\mathrm{a}}$ & $38.32 \pm 2.32^{\mathrm{a}}$ & $41.22 \pm 3.55^{\mathrm{a}}$ \\
\hline
\end{tabular}

"(a,b): Different superscripts within the same column differ significantly $(\mathrm{p}<0.01)$ ".

M-O: Milk without antioxidant, M-C: Milk with $5 \mathrm{mM}$ cysteine, M-H: Milk with $1000 \mu \mathrm{g} / \mathrm{ml}$ hyaluronic acid

Table 4. Post-thaw spermatologicial characteristics of buck semen frozen in laiciphos extender containing different antioxidants $(\mathrm{n}=10)$

Tablo 4. Farklı antioksidanlar içeren laiciphos sulandırıcısıyla dondurulmuş teke spermasında çözdürme sonrası spermatolojik özellikler $(\mathrm{n}=10)$

\begin{tabular}{lccccc}
\hline Groups & $\begin{array}{c}\text { Motility } \\
(\%)\end{array}$ & $\begin{array}{c}\text { Viability } \\
(\%)\end{array}$ & $\begin{array}{c}\text { Total abnormality } \\
(\%)\end{array}$ & $\begin{array}{c}\text { Acrosomal abnormality } \\
(\%)\end{array}$ & $\begin{array}{c}\text { Host } \\
(\%)\end{array}$ \\
\hline L-O & $37.5 \pm 1.86^{\mathrm{ab}}$ & $42.50 \pm 1.56^{\mathrm{ab}}$ & $56.34 \pm 2.24^{\mathrm{a}}$ & $40.01 \pm 2.73^{\mathrm{a}}$ & $45.25 \pm 2.59^{\mathrm{a}}$ \\
L-C & $42.0 \pm 2.49^{\mathrm{a}}$ & $46.67 \pm 1.77^{\mathrm{a}}$ & $54.78 \pm 2.23^{\mathrm{a}}$ & $36.31 \pm 1.96^{\mathrm{a}}$ & $42.75 \pm 2.95^{\mathrm{a}}$ \\
L-H & $32.0 \pm 1.33^{\mathrm{b}}$ & $39.59 \pm 1.09^{\mathrm{b}}$ & $52.44 \pm 2.49^{\mathrm{a}}$ & $36.38 \pm 2.39^{\mathrm{a}}$ & $41.42 \pm 3.20^{\mathrm{a}}$ \\
\hline
\end{tabular}

"(a,b): Different superscripts within the same column differ significantly $(\mathrm{p}<0.01)$ ".

L-O: Laiciphos without antioxidant, L-C: Laiciphos with $5 \mathrm{mM}$ cysteine, L-H: Laiciphos with $1000 \mu \mathrm{g} / \mathrm{ml}$ hyaluronic acid

\section{Discussion and Conclusion}

The ROS generation, induced by cryopreservation process, might be responsible for the mammalian sperm damage. ROS production has been associated with the reduction of sperm motility, decreased capacity for sperm-acolyte fusion and infertility. Sperm cells are sensitive to lipid peroxidation due to their high content of polyunsaturated fatty acids, and they are unable to resynthesize their membrane components; however, this may not be the sole mechanism by which sperm function is impaired by the $\operatorname{ROS}(13,19)$.

Thiol compounds, such as cysteine, are the precursors of intracellular GSH biosynthesis, and cysteine protects the sperm cells from toxic oxygen metabolites causing lipid peroxidation of the sperm plasma membrane in vitro (18). Adding cysteine to the freezing extender enhanced post-thaw motility of goat and ram spermatozoa $(3,6,26)$ and improved membrane integrity of boar spermatozoa (11). Indeed, marked improvements both in sperm motility and viability were obtained by tris extender containing cysteine used in the present study. However, it did not affect the sperm abnormality, acrosomal damage and membrane integrity observed herein. It is possible that our results might be reflecting an inappropriate concentration of cysteine for buck semen. Uysal and Bucak (26) demonstrated that increasing doses of cysteine $(15 \mathrm{mM})$ decreased postthaw sperm abnormality and acrosomal damage in rams. On the other hand, cysteine did not influence the percentage of motile spermatozoa, viability, the sperm abnormality, acrosomal damage and membrane integrity in semen diluted in skimmed milk or laiciphos extender. Because of the presence of casein (as natural antioxidant) in milk, as also used herein, this might account for the fact that an array of antioxidants was not beneficial to sperm cells for skimmed milk extender. 
In the last few years, it has been reported that supplementation of semen extenders by hyaluronic acid maintains good spermatozoal motility in human (12) and goats (15). It was also favourable for maintaining the membrane stability and viability of spermatozoa in boars (20). However, Mari et al. (16) demonstrated that its addition did not improve the post-thaw motility of equine spermatozoa. Moreover, in the present study, hyaluronic acid in skimmed milk-based extender markedly deteriorated the spermatozoal motility. To our knowledge, this is the first report which documents on the toxic effect of hyaluronic acid at the dose level of $1000 \mu \mathrm{g} / \mathrm{ml}$ on the motility of goat sperm. This could possibly be due to an antioxidant effect of the extender (skimmed milk) itself. Apparently, one may assume that, high doses of the antioxidant additives may exert deteriorating effect on the functional integrity of the axonemal and mitochondrial structures, as both associated with the motility. It is likely that, the present results could represent an inappropriate concentration of hyaluronic acid in the extender for buck semen. Indeed, its concentration $(1000 \mu \mathrm{g} / \mathrm{ml})$ used herein was directly adopted from those studies conducted in human and boar semen. Adding hyaluronic acid $(1000 \mu \mathrm{g} / \mathrm{ml})$ to the freezing extender enhanced post-thaw motility of boar and human sperm $(11,12)$. Contradictory reports existing on the effect of antioxidant supplementation on postthaw motility of semen from various species, including the buck $(4,8,17,24,25)$, were resulted from the different the types and doses of the antioxidants employed. These equivocal results may be related not only to the different degrees of susceptibility of sperm cells (among the species) to lipid peroxidation, but also due to the differences in the contents of antioxidants and/or the composition of seminal plasma concerned.

In conclusion, firstly, the present findings suggest that milk-based extenders may result in superior protective performance in vitro as compared to those particularly with tris-base. Secondly, cysteine, as an antioxidant, provided a superior protection than the hyaluronic acid did. More studies are needed in order to determine in vivo goat fertility, to find the appropriate antioxidants and to define the most effective concentrations, which will improve post-thaw quality and increase fertility when frozen-thawed buck semen is used.

\section{Acknowledgement}

Authors gratefully acknowledge Assist.Prof.Dr. Ömer Uçar (Atatürk University, Erzurum) for his kind contributions with English as well as critical reading and valuable comments on the manuscript.

\section{References}

1. Aitken RJ, Clarkson JS (1989): Significance of reactive species and antioxidants in defining the efficacy of sperm preparative techniques. J Androl, 9, 367-376.

2. Alvarez JG, Storey BT (1983): Role of superoxide dismutase in protecting rabbit spermatozoa from $\mathrm{O}_{2}$ toxicity due to lipid peroxidation. Biol Reprod, 28, 11291136.

3. Ateşşahin A, Bucak MN, Tuncer PB, Kızıl M (2008): Effect of anti-oxidant additives on microscopic and oxidative parameters of Angora goat semen following the freeze-thawing process. Small Rum Res, 77, 38-44.

4. Aurich JE, Schonherr U, Hoppe H, Aurich C (1997): Effect of antioxidants on motility and membrane integrity of chilled stored stallion semen. Theriogenology, 48, 185192.

5. Balogh GT, Illes J, Szekely Z, Forrai E, Gere A (2003): Effect of different metal ions on the oxidative damage and antioxidant capacity of hyaluronic acid. Arch Biochem Biophys, 410, 76-82.

6. Bucak MN, Uysal O (2008): The role of antioxidants in freezing of Saanen goat semen. Indian Vet J, 85, 148-150.

7. Daniel WW (1991): Analysis of variance. In: Biostatistics: Daniel, W.W. (Ed.). A Foundation for Analysis in the Health Sciences. John Wiley and Sons, Hoboken, pp: 274320.

8. Donnelly ET, McClure N, Sheena E, Lewis EM (1999): Antioxidant supplementation in vitro does not improve human sperm motility. Fertil Steril, 72, 484-495.

9. Evans G, Maxwell WMC (1987): Salamon's Artificial Insemination of Sheep and Goats. Sidney: Butterworths, pp. 8-21, 107-141.

10. Foote RH, Brockett CC, Kaproth MT (2002): Motility and fertility of bull sperm in whole milk extender containing antioxidants. Animal Reprod Sci, 71, 13-23.

11. Funahashi H, Sano T (2005): Select antioxidants improve the function of extended boar semen stored at $10^{\circ} \mathrm{C}$. Theriogenology, 63, 1605-1616.

12. Huszar G, Willets M, Corrales M (1990): Hyaluronic acid (sperm select) improves retention of sperm motility and velocity in normospermic and oligospermic specimens. Fertil Steril, 54, 1127-1134.

13. Griveau JF, Le Lannou D (1997): Reactive oxygen species and human spermatozoa: physiology and pathology. Int J Androl, 20, 61-69.

14. Güney O, Tuncel E, Biçer O (1989): The potential of the Mediterranean goat populations with special reference to Mediterranean and Aegean parts of Turkey. Proceedings of the International Symposium on the Constraints and Possibilities of Ruminant Production in the Dry Subtropics. 5-7 November, 1988. EAAP publication, 38.

15. Mara L, Dattena $M$, Pilichi $S$, Sana $D$, Branca $A$, Cappai P (2007): Effect of different diluents on goat semen fertility. Anim Reprod Sci, 102, 152-157.

16. Mari G, Lacono E, Rizzato G, Merlo B, Belluzzi S (2005): Effect of hyaluronic acid supplementation on motility of stallion spermatozoa after cryopreservation. Anim Reprod Sci, 89, 284-285.

17. Maxwell WMC, Stojanov T (1996): Liquid storage of ram semen in the absence or presence of some antioxidants. Reprod Fertil Dev, 8, 1013-1020. 
18. Meister A, Tate SS (1976): Glutathione and related gamma-glutamyl compounds: biosynthesis and utilization. Ann Rev Biochem, 45, 559-604.

19. Neild DM, Gabella BM, Chaves MG, Miragaya MH, Colenbrander B, Aguero A (2003): Membrane changes during different stages of a freeze-thaw protocol for equine semen cryopreservation. Theriogenology, 59, 1693-1705.

20. Pena, FJ, Johannisson AM, Rodriguez-Martines H (2004): Effect of hyaluronan supplementation on boar sperm motility and membrane lipid architecture status after cryopreservation. Theriogenology, 61, 63-70.

21. Purdy PH (2006): A review on goat sperm cryopreservation. Small Rum Res, 63, 215-225.

22. Revell G, Mrode RA (1994): An osmotic resistance test for bovine semen. Anim Reprod Sci, 36, 77-86.

23. Schafer S, Holzmann H (2000): The use of transmigration and spermac stain to evaluate epididymal cat spermatozoa. Anim Reprod Sci, 59, 201-211.

24. Sinha MP, Sinha AK, Singh BK, Prasad RL (1996): The effect of glutathione on the motility, enzyme leakage and fertility of frozen goat semen. Anim Reprod Sci, 41, 237-243.
25. Upreti GC, Jensen K, Oliver JE, Duganzich DM, Munday R, Smith JF (1997): Motility of ram spermatozoa drying storage in a chemically-defined diluent containing antioxidants. Animal Reprod Sci, 48, 269-278.

26. Uysal O, Bucak MN (2007): Effects of oxidized glutathione, bovine serum albumin, cysteine and lycopene on the quality of frozen-thawed ram semen. Acta Vet Brno, 76, 383-390.

Geliş tarihi: 23.02.2009 / Kabul tarihi: 31.07.2009

Address for correspondence:

DVM PhD Recai Kulaksiz,

Ankara University, Faculty of Veterinary Medicine,

Department of Reproduction and Artificial Insemination, 06110, Diskapi-Ankara, Turkey.

e-mail: recaikulaksiz@gmail.com 